
this study showcases a range of appreaches in the study of these phenomena in Europe and the world and underscores the valuable contribution political psychology has made in generating answers to timely research questions:

individual ahapters from the worl d: 5 top experts in the field explore the ways in which political psychology impacts on issues as diverse as mirration conflict and violence as well as electora Dolitics while also situating the discipline within the realm of pelitical decisionemaking and Poficy on important debates relating to foreich policy and ralations political participation and terrorism among a variety of other issues.

Furthermore, the collection offers analyticalitlustrations of Soctal tentity Theory

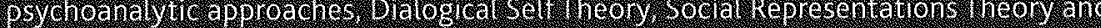
Self-Categonsation Theory, allowing for an in-depth engagement across theoretical contributions to the fieid:

Using theoretical and methodological approaches in conjunction with empirical evidence. his.

Study or harbour an interest in political psychology

Paul Nesbitt Larking is Professor of Political Science at Huron University College, Canada. His recent publicatians include Politics Soalety and the Media (2009) The Political Paycholom of elobalization: Musilims in the West (2017) as well as numerous academic articles and book chapters He is President of the international Society of Political Psychology (ISPP)

Catarina Kinnvali is Professor at the Department of Poitical Selence, Lund University, Sweden

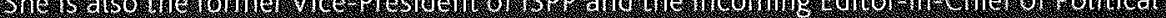

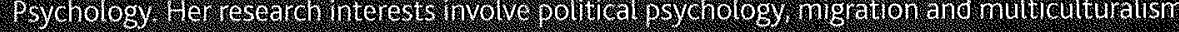
globalisation religion and nationalism, with a pariticular focus on South Asia and Europe.

Tereza Capelos is Senior Lecturer in Political Psychology at the University of Surrey, UK: Vice-President of ISPD, Co-Chair of the ECPR (European Consortium for Political Research) Poifical Psyehology standing Group and Director of the ISPP Summer Acadeny. She examines the affective and cognitive ceterminants of political juogemenis and spectal ses in reputation Jomation andmanagement of crisis:

Henk Dekker is Professor of Political Socialization and integration and Vice- Dean of the Facultiy of Social and Be havioural Sciences of Leiden University the Netherlands and co-chat of the ECPR Political Psychology Standino Group His research focuses on explaining eitizens politica

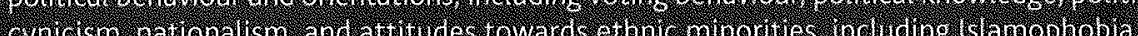
and at titudes towards foreign countries and international cooperation

\title{
palgrave macmillan
}

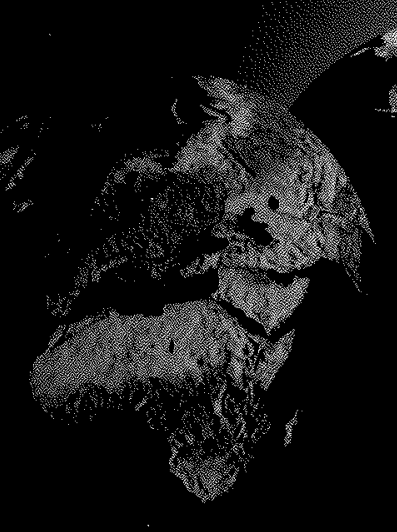

by Paul Nesbitt-Larking,

Kinnvall \& Tereza Capelos

with Henk Dekker 
Paul Nesbitt-Larking Catarina Kinnvall, and Tereza Capelos (editors) 作 Lisa Strombom

ISRAELIDENTITY, THICK RECOGNITION AND CON
32 NES,

The Palgrave Handbook of Global Political Psychology

Edited by

Paul Nesbitt-Larking

Department of Political Science, Huron University College, Canada

Catarina Kinnvall

Department of Political Science, Lund University, Sweden

Tereza Capelos

Department of Politics, University of Surrey, UK

With

Henk Dekker

Graduate School of Social and Behavioural Sciences, Leiden University, The Netherlands
Palgrave Studies in Political Psychology Series

Series Standing Order ISBN 978-1-137-03466-3 (hardback)

and 978-1-137-03467-0 (paperback)

utside North America only)

You can receive future titles in this series as they are published by placing a standing Order. Please contact your bookseller or in case of difficulty, write to us at the address below with your name and address, the title of the series and the ISBN quoted above.

Customer Services Department, Macmillan Distribution Ltd, Houndmills, Basingstoke, Hampshire RG21 6XS, England 
any person who does any unauthorized act in relation to this publication

may be liable to criminal prosecution and civil claims for damages. The authors have asserted their rights to be identified as the ang.

First published 2014 by Palgrave Macmillan in the UK is an imprint of Macmillan Publishers Limited, registered in England,
Hampshire RC221 6 XS.

政 in the US is a division of St Martin's Press LLC

175 Fifth Avenue, New York, NY 10010

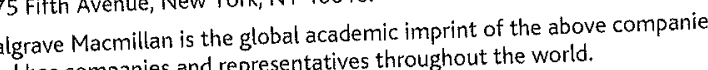

Palgrave $\Theta^{\circledR}$ and Macmillan ${ }^{\circledR}$ are registered trademarks in the United States,

the United Kingdom, Europe and other countries:

ISBN 978-1-137-29117-2

This book is printed on paper suitable for recycling and made from fully managed and sustained forest sources. Logging, pulping and manufacturing

processes afe expecte
country of origin.

A catalogue record for this book is available from the British Library

Library of Congress Cataloging-in-Publication Data
The Palerave handbook of global political psychology : edited by, Tereza Capelos, senio lecturer in Poiltical psychology, Delitical Science, Department of Political Science, Lund Unversity, Sweden; edited by, Paul Nesbitt-Larking, professor of Political Science and Visiting Protessor, Department of Poll kal sces University of -

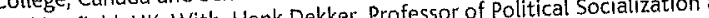
Hudderstield, Graduate School of Social and Behavioural Sciences, Ledien University, The Netherlands. pages $\mathrm{cm}$. - (Palgrave studies in political psychology) (The discipline most important and hotly contested issues. Advancing on this tudy showcases a psychoological mechanisms that dis of these phenomena in Europe and the world and range of approaches in hle contribution political psychology has made in generating answers to timely research questions. Individual chapters fion experts in the field explores the ways in which pollcical pyel as electoral politics issues as drive ferting and policy on important debates relating to foreign policy and relations, political participation and terrorism amongst a vant collection offers analytical thastrath social Representations Theory and Self-Cate is tistion Theory, allowing for an in-depth engagement across theoretical contributions to the field. Using theoretical and mothopos the diverse field of conjunction with empin its entirety and explores its future direction. The resulting political psychology in its entirety and explores those who study or harbour an

Political psycholoyy-Cross-cultural studies. 2. World politics. Capelos, Tereza 327.101' $19-d c 23$

Acknowledgements

Notes on Contributors

\section{Part I Introduction}

1 Introduction: Origins, Developments and Current Trend Paul Nesbitt-Larking, Catarina Kinnvall, Tereza Capelos and Henk Dekker

Part II Methodological Approaches

2 Social Representations and the Politics of Participation Caroline Howarth, Eleni Andreouli and Shose Kesst

3 Social Identity Theory and Self-Categorisation Theory Denis Sindic and Susan Condor

4 Psychoanalysis as Political Psychology Stephen Frosh

5 Methodological Approaches in Political Psychology: Discourse and Narrative Phillip L. Hammack and Andrew Pileck

6 Dialogical Approaches to Psychology and Ethics Sarah Scuzzarello

7 Experiments: Insights and Power in the Study of Causality Tereza Capelos

\section{Part III Themes}

8 Lessons from the Postcolony: Frantz Fanon, Psychoanalysis and a Psychology of Political Critique Ross Truscott and Derek Hook

9 Conflict Analysis and International Relations Karin Aggestam 
10 'Do Terrorists Have Goatee Beards?' Contemporary Understandings of Terrorism and the Terrorist James W. McAuley

11 Gender, Race and Ethnic Relations Sebastian E. Bartoş and Peter Hegarty

12 Voting and Not Voting: The Principal Explanations Henk Dekker

Part IV Hot Issues

13 Political Emotions Nicolas Demertzis

14 Group-Focused Enmity: Prevalence, Correlations and Causes of Prejudices in Europe Beate Küpper and Andreas Zick

15 Political Psychology of European Integration Ian Manners

16 Migration and Multiculturalism Paul Nesbitt-Larking

17 Political and Civic Participation among Ethnic Majority and Minority Youth Dimitra Pachi, Theopisti Chrysanthaki and Martyn Barrett

18 Fear, Insecurity and the (Re)Emergence of the Far Right in Europe Catarina Kinnvall

19 A Political Psychology of Conflict: The Case of Northern Ireland Neil Ferguson, Orla Muldoon and Shelley McKeown

20 Narrating Moments of Political Change Molly Andrews

21 The Culture of Conflict and Its Routinisation Daniel Bar-Tal, Guy Abutbul-Selinger and Amiram Raviv

22 Narrative Constructions of Conflict and Coexistence: The Case of Bosnia-Herzegovina Johanna Mannergren Selimovic

23 Political Socialisation and Social Movements: Escaping the Political Past? Igor Petrović, Jacquelien van Stekelenbury and Bert Klandermans
Part V Conclusion

24 Ideology, Society and the State: Global Political Psychology in Retrospect

Paul Nesbitt-Larking

25 Afterword: For Inspiration and the Future Paul Nesbitt-Larking, Catarina Kinnvall, Tereza Capelos and Henk Dekker 


\section{Notes on Contributors}

Guy Abutbul-Selinger is a post-doctoral student in the Sociology Department Tel Aviv Univest Tel Aviv University, Israe, and teaches in the Sociology Den University, UK. He completed his PhD in Sociology at Brandeis University, USA His research deals with the new ethnicity in the Israeli middle class and with the routinisation of the Israeli-Palestinian conflict into Israeli everyday life.

Karin Aggestam is Associate Professor of Political Science and Director of Peace and Conflict Research, Lund University, Sweden. She has published widely on conflict resolution, peace-building, hydro-politics, diplomacy, negotiation/mediation and the Israeli-Palestinian conflict. Some of her most recen tiation/medilacebuilding (co-authored with Ann publications are Situating Wato in Peaceblination of Peace NGOS (co-authored Sundel1, 2014), Disempowerment and Marginalisation of Peace NGOs (co-authored with Lisa Strömbom, Peacebuilding, 2013) and Rethinking Peacebuilding: The Quest for Just Peace in the Middle East and the Western Balkans (co-edited with Annika Björkdahl, 2013).

Eleni Andreouli is Lecturer in the Psychology Department of the Open Univer(hocial psychology of citizensity, UK. Her primary research interests lie in the social psychology of citizenship, immigration and identity in diverse societies. Her research includes work on British citizenship and immigration, focusing particularly on naturalisation as a border-crossing practice. She has also researched intercultural relations in as a border-crossing pring how we can develop effective multicultural educaschool settings, studying how we can dever culturally diverse societies. tional policies in the context of Britain and other culturally diverse societies. She has published articles in the Journal for the Theory of Social Behaviour, Culture \& Psychology, Journal of Community and Applied Social Psychology and Journal of Health Psychology, among others, as well as chapters in edited volumes. She is co-ditor of the forthcoming Cambridge Handbook of Social Representations.

Molly Andrews is Professor of Political Psychology and Co-director of the Centre for Narrative Research (www.uelac.uk/cnr/index.htm) at the University of East London, UK. Her research interests include political narratives, the psychological basis of political commitment, political identity, patriotism and aging. She is currently working on a project called The Unbuilding of East and aging. She is cun Germany: Excavating Biography and History. Her books include Lifetimes of Commitment: Aging, Politics, Psychology; Shaping History: Narratives of Political Change; and Narrative Imagination and Everyday Life (2014).
Martyn Barrett is Emeritus Professor of Psychology at the University of Surrey UK. He works on intercultural competence, national and ethnic enculturation, acculturation processes, the development of intergroup attitudes, and tivic and political participation ous research grants from the European Commission, the Economic and Social Research Council, the Nuffield Foundation, the Leverhulme Trust and various other bodies. From 2009 to 2012, he led a project funded by the European Commission, under the Seventh Framework Programme, entitled 'Processes Influencing Democratic Ownership and Participation (PIDOP)' (www.fahs.surrey.ac. $\mathrm{uk} / \mathrm{pidop} /$ ). He also works as an expert for the Council of Europe on compe$\mathrm{uk} / \mathrm{pidop} /$ ). He also works as an expert for the Council of Europe on compe-
tences for democracy and intercultural dialogue. He is a Fellow of the British Psychological Society and A Fellow of the Academy of Social Sciences.

Daniel Bar-Tal is Branco Weiss Professor of Research in Child Development and Education at the School of Education, Tel Aviv University, Israel. His research interest is in political and social psychology, studying socio-psychological foundations of intractable conflicts and peace-building, as well as development of political understanding among children and peace education. He has published 20 books and over 200 articles and chapters in major social and political psychological journals, books and encyclopaedias. He served as the President of the International Society of Political Psychology and received various awards for his work, including the Lasswell Award and the Nevitt Sanford Award.

Sebastian E. Bartos is currently pursuing doctoral research at the University of Surrey, UK. He holds an MA in Clinical Psychology from the Babeş-Bolyai University in Cluj-Napoca, Romania. His PhD thesis, supervised by Peter Hegarty, focuses on strategies to reduce homophobia. Sebastian's primary interest is in eastern European sexualities, and he has published papers on media portrayals of gay people, online personal advertisements and gay men's bereavement. He is also interested in methodological pluralism, and his own research employs such diverse methods as meta-analysis and discourse analysis.

Tereza Capelos is Senior Lecturer in political psychology at the University of Surrey. She holds a $\mathrm{PhD}$ in Political Science and Electoral Behavior, and her research examines the affective and cognitive determinants of political judgements. She specialises in electoral behaviour, public opinion and quantitative research methods with particular focus on candidate evaluations, impression formation, reputation management, political scandals and accountability, emotions in times of crisis, political tolerance, political knowledge and 
civic competence. She has extensive experience in experimental design, survey methodology, content analysis and statistics. Tereza is vice president of the International Society of Political Psychology, co-chair of the ECPR Political Psychology Standing Group, and Director of the International Society of Political Psychology Summer Academy (ISPP-SA).

Theopisti Chrysanthaki is Lecturer at the London School of Hygiene and Tropical Medicine, University of London, UK. She holds an MSc and PhD in Social Psychology from the University of Surrey, UK. Theopisti has held positions at Imperial College London, Queen's University Belfast and the University of at lirrey where she worked in a multinational project on political trust and parsurney where she worked in a muting ticipation among young people from ethnic minorities in the New Independent States (NIS) and EU. Her research interests focus on identity construction and development and multiple identities with a particular focus on immigration, acculturation and political participation of young people and minority groups in multicultural societies. Recently, she has developed research that studies the inovations in health care services and impact of large transformational policy innovations in health care services and identities and published papers in peer-reviewed journals and chapters in edited books.

Susan Condor is Professor of Social Psychology at Loughborough University UK . ogy renders social identities personally and politically meaningful in different ways. Her subsequent work has focused on national ideologies and identities in the United Kingdom; the relationship between social identity and citizenship; and dilemmas of everyday liberalism.

Henk Dekker is Professor of Political Socialization and Integration at the Faculty of Social and Behavioural Sciences of Leiden University and vice-dean of this faculty. He studied Political Science at the Free University in Amsterdam, received his $\mathrm{PhD}$. from Groningen University, was Professor for the Social-Scientific Study of the Germany-Netherlands Relations at Utrecht University and served as Director of the European Research Centre on Migration and Ethnic Relations. In 2006, he received the Nevitt Sanford Award from the International Society of Political Psychology.

Nicolas Demertzis is Professor at the Faculty of Communication and Media Studies, Athens University, Greece, and Director of the Greek National Centre for Social Research (EKKE). He has taken part in numerous conferences and has published extensively in Greek and English journals and collective volumes. His current academic and research interests include political sociology, political communication and the sociology of emotions. He is editor of Emotions in Politics: The Affect Dimension in Political Tension (2013). His previous publication include Enuy and Resentiment: The Passions of the Soul and the Closed Society (with Thanos Lipowatz 2006), Political Communication: Risk, Publicity and the Internet (2002) and The Nationalist Discourse: Ambivalent Semantic Field and Contemporary Tendencies (1996)

Neil Ferguson is Professor of Political Psychology at Liverpool Hope University UK. He has been the Director of the Desmond Tutu Centre for War and Peace Studies; a Visiting Lecturer to Lock Haven University of Pennsylvania and the University of York, UK; a Research Fellow at University of St Andrews, UK; and previously lectured at the University of Ulster, UK. His research and writings deal with moral development and a number of topics located within politideal with mor dic cal psychology. Professor Ferguson is curnently the President of the Moral and Social Action Interdisciplinary Colloquium, a member of the Editorial Boards of The Journal of Moral Education and The Journal of Social and Political Psychology and treasurer for the Journal of Moral Education Trust.

Stephen Frosh is Pro-Vice-Master and Professor in the Department of Psychosocial Studies at Birkbeck College, University of London, UK. He is the author of many books and papers on psychosocial studies and on psychoanalysis, including Psychoanalysis Outside the Clinic (2010), Hate and the Jewish Science: Anti-Semitism, Nazism and Psychoanalysis (2005), For and Against Psychoanalysis (2006) After Words (2002) and The Politics of Psychoanalysis (1999). His most recent books are Hauntings: Psychoanalysis and Ghostly Transmissions (2013), Feelings (2011) and A Brief Introduction to Psychoanalytic Theory (2012).

Phillip L. Hammack is Associate Professor of Psychology and Director of the (PCI) Laboratory at the University of California, Santa Cruz, USA. He was trained in the interdisciplinary Committee on Human Santa Cruz, USA. He was trained in the interdisciplinary Committee on Human
Development at the University of Chicago, USA, and studies individual experience in social and political context. Hammack has published widely in social, cultural, developmental and political psychology. He is author of Narrative and the Politics of Identity: The Cultural Psychology of Israeli and Palestinian Youth (2011), co-editor (with B. J. Cohler) of The Story of Sexual Identity: Narrative Perspectives on the Gay and Lesbian Life Course (2009) and editor of the forthcoming Oxford Handbook of Social Psychology and Social Justice (2015)

Peter Hegarty is Professor and Head of the School of Psychology at the University of Surrey, UK. His interests intersect social psychology, history of science and gender and sexuality studies. His first book Gentleman's Disagreement: Alfred Kinsey, Lewis Terman and the Sexual Politics of Smart Men (2013) re-examines the 
relationships between the IQ testing movement and the sex survey from the vantage point of the relationship between leaders in these movements. Peter's recent work has been published in such venues as British Journal of Psychology, History of the Human Sciences, Social and Personality Psychology Compass and Perspectives on Psychological Science. Interviews with Peter have been published on the Scientific American's 'Doing Good Science' blog and on the website of the project 'Psychology's Feminist Voices' (www.feministvoices.com).

Derek Hook is Reader in Psychosocial Studies at Birkbeck College, University of London, UK. Visiting Lecturer at the London School of Economics and Political Science, UK. and Extraordinary Professor in Psychology at the University of Pretoria, South Africa. He is the author of A Critical Psychology of the Postcolonial (2011), Biko: Voice of Liberation (2012) and (Post)apartheid Conditions (2013).

Caroline Howarth is Associate Professor in the Department of Social PsycholCoy at the London School of Economics and Political Science, UK. She has A a commitment and passion for developing social psychology as a discipline in ways that intersect with current social and political concerns, revealing the necessity of the psychological analysis of 'real-world' issues that lead to programmes for social change. Growing up in multicultural communities (in Kenya South Africa, Papua New Guinea and Fiji) influenced the way she (In Kenya, South Africa, Pa 'does' social psychology, directing her interests towards the political interconnections between community, identity, representation and resistance. She is particularly interested in the political implications of connections between identity and representation for participation, intergroup dialogue and socia change. She is Editor of Papers on Social Representations and publishes widely in social, community and political psychology.

Shose Kessi is Lecturer in the Department of Psychology at the University of Cape Town, South Africa. Her research centres on community-based empowerment and social change, particularly exploring how to address issues of identity, such as race and gender, that impact on people's participation in community development efforts. Her current work focuses on the development of photovoice methodology as a research tool that can raise consciousness and mobilise young people and community groups into social action. Her work has been published in South African and international journals.

Catarina Kinnvall is Professor at the Department of Political Science, Lund University, Sweden. She is also the former Vice-President of the International Society of Political Psychology (ISPP). Her research interests involve political psychology, migration and multiculturalism, globalisation and security, religion and nationalism, with a particular focus on South Asia and Europe. She is the author of a number of books and articles. Some of her publications include: 'Borders, Security and (Global) Governance', (2013, special issue editor) Global Society, 27 (3); The Political Psychology of Globalization: Musinis (co-ed., 2011); On Behalf of Others: The Psychology of Care in a Global World (co-ed., 2009): Globalization and Religious Nationalism in India: The Search for Ontological Security (2006).

Bert Klandermans is Professor of Applied Social Psychology at the VUUniversity, Amsterdam, the Netherlands. He has published extensively on University, Amsterdam, the Netherlands. He has published extensively on
political protest and movement participation. He is the author of the now classic Social Psychology of Protest (1997). He is the editor and co-author (with Suzanne Staggenborg) of Methods of Social Movement Research (2002) and (with Nonna Mayer) Extreme Right Activists in Europe (2006). With Conny Roggeband, he edited the Handbook of Social Movements Across Disciplines (2007). He is coeditor of Encyclopedia of Social Movements and The Future of Social Movement Research: Dynamics, Mechanisms, and Processes (2013). In 2013, he received the Harold Lasswell Award of the International Society of Political Psychology for his lifelong contribution to political psychology. In 2014, he received the John D. McCarthy Award from Notre Dame University, USA, for his contribution to the study of social movements and collective action.

Beate Küpper is Professor in the Department of Social Work at the University of Applied Science Niederrhein, Germany. She coordinated the study on Group-Focused Enmity in Europe and a related ten-year project in Germany. Her research interests include prejudice and discrimination, the impact of social status and social dominance orientation, as well as the issues of integration and diversity in the societal and working context.

Ian Manners is Professor in the Department of Political Science at the University of Copenhagen, Denmark. His research interests lie at the nexus of critical social theory and the study of the EU in global politics. He is author of 'European Communion: Political Theory of European union' (Journal of European Public Policy 20:4, 2013); 'Symbolism in European Integration' (Comparative European Politics 9, 2011): 'Global Europa: the Mythology of the (n) Common Market Studies 48:1, 2010); 'Another Europe Is Possible: Critical Perspectives on EU Politics' in Handbook of European Union Politics (2007); 'Normative Power Europe: A Contradiction in Terms?' (Joumal of Common Market Studies 40:2, 2002). He has also authored and edited six books, most recently Research Methods in EU Studies (Palgrave, 2014); The Foreign Policies of EU Member States (2014); and The European Project: Politics and Law - History and Future (2013). 
James W. McAuley is Professor of Political Sociology and Irish Studies, Associate Dean for Research and Enterprise and Co-director of the Institute for Research in Citizenship and Applied Human Sciences, School of Human and Health Sciences, University of Huddersfield, UK. He is the author of numerous journal articles and books, including Ulster's Last Stand?: (Re)constructing Ulster Jnionism after the peace procss (2010); Abandoning Historical Conflict? Former Unionism after the peace process (2010), Abanding Historcal Conflet? Former Paramilitary Prisoners and Political Reconciliation in Northern lreland (2010); and Loyal to the Core? Orangeism and Britishness in Northern Ireland (2011).

Shelley McKeown is Assistant Professor of Psychology at Leiden University College, The Hague She obtain a BSc in social psychology in 2008 followed by a PhD in 2012 , both from the University of Ulster, UK. During her PhD she worked alongside Professor Ed Cairns as part of the peace and conflic research group. McKeown's research interests lie within the areas of social, polit ical and peace psychology - specifically understanding and improving group iche methods to reduce prejudice. McKeown has published a number of journal articles, book chapters and, recently, written a book on identity, segregation an peace-building in Northern Ireland.

Orla Muldoon was awarded a PhD from Queens University Belfast, UK. She was a John F. Kennedy Scholar in 1996 and studied during that time in the University of Michigan, USA, before taking up her first academic position at University of Ulster, UK. She subsequently joined Queens University Belfast (1998) and later the University of Limerick, Ireland. She is the Foundation Chair at the University of Limerick She has served as a member of the governing council of the International Society of Political Psychology and has widely published in highimpact international peer-reviewed journals on the impact of conflict both our sense of selves and identity as well as on child and adult health.

Paul Nesbitt-Larking is Professor of Political Science at Huron University ColPaut in lege in Cant University of Huddersfield, UK. A scholar in political identities, citizenship multiculturalism and political communications, his recent publications include Politics, Society, and the Media (2009), the Political Psychology of Globalization: Muslims in the West (2011, co-authored with Catarina Kinnvall), as well as numerous academic articles and chapters. He is currently President of the International Society of Political Psychology.

Dimitra Pachi is Lecturer in Psychology at the BPP University, UK. She has degrees from the National and Kapodistrian University of Athens, Greece, and from the University of Surrey, UK, She has conducted multi-methodological national and international research on young people on the issues of political/civic participation, im/migration and inter/intra-national conflict resolution, with a particular focus on social and political trust, political efficacy, group tion, with a particular focus on social and political trust, political efficacy, group identification and intergroup emotions. She has presented her work in numersocial psychology and she has published papers in peer-reviewed journals and chapters in edited books. She is currently in the process of writing a book, with Professor Martyn Barrett, on young people's political and civic participation.

Igor Petrović is a $\mathrm{PhD}$ candidate at the VU-University, Amsterdam, the Netherlands. He has a background in political science and is interested in political socialisation, political participation and military sociology. He worked as an assistant on a study on emerging networks and feelings of belonging: The Evolution of Collective Action in Emerging Neighbourhoods (funded by Dutch Royal Academy of Science) under the supervision of Jacquelien van Stekelenburg. His current project focuses on work-related discontent and voice among Dutch military personnel.

Andrew Pilecki is a doctoral student in Social Psychology at the University of California, Santa Cruz, USA. His research examines intergroup violence from a moral psychology perspective. He is also the founder of the Moral Communities Project, which is a research organisation that examines the relationship between morality and politics as well as promotes public social science.

Amiram Raviv is a school and clinical psychologist, Dean of the School of Psychology in the Center for Academic Studies, Or Yehuda, Israel, and Professor Emeritus at the School of Psychological Sciences, Tel Aviv University, Israel. Formerly Head of the Psychology Department, Tel Aviv University, Israel, Proressor journals and books and is co-editor and co-author of six books. His research interests include school psychology, children's cognitive development, helpseeking, social cognition and various psychological mechanisms that operate in societies in intractable conflict. In addition to his academic activities, he in societies in the Ministry served as head psychologist a of Education in Israel and has participated in the preparation of enrichmen books for children, as well as of psycho-educational resources for parents and grandparents.

Sarah Scuzzarello is Associate Lecturer at the School of Politics, University of Surrey, UK. Her research draws upon political science and social psychology and is topically focused on processes of collective identification, ethnic relations and public policy concerning migrant integration. Her work has recently been 
published in Political Psychology, Ethnic and Racial Studies, Journal of Community and Applied Social Psychology, Feminist Theory, among others.

Johanna Mannergren Selimovic is a post-doctoral research fellow at the Swedish Institute of International Affairs, Stockholm, Sweden. Her research Swedish thstitute of lntention concerns peace-building with a special interest in transitional justice, reconciliation processes, the politics of memory and gender. She is currently involved in two research projects: Gender and Transitional Justice and Divided Cities - Challenges to Post-Conflict Peacebuilding and Development. Recent publications include Making Peace, Making Memory: Peacebuilding and Politics of Remembrance at Memorials of Mass Atrocities' (Peacebuilding, 2013), 'Gendered Justice Gaps in Bosnia-Herzegovina' (co-authored with Annika Björkdahl, Human Rights Review, 2013) and 'Silence as Possibility in Post-War Everyday Life' (co-authored with Marita Eastmond, International Journal of Transitional Justice, 2012).

Denis Sindic is a Research Fellow at the Institute of Social Sciences of the University of Lisbon, Portugal. He did his PhD under the supervision of Stephen Reicher at the University of St Andrews, UK, on political attitudes towards national separatism and supranational integration. His current research focuses on the political psychology of immigration and the role of national and European identities in attitudes towards the European Union.

Jacquelien van Stekelenburg is Associate Professor in the Department of Sociology, VU-University Amsterdam, the Netherlands. She studies the social psychological dynamics of protest participation, with a special interest in group identification, emotions and ideologies as motivators for collective action. She has co-authored (with Klandermans) the chapter 'Individuals in Movements: A Social Psychology of Contention' (The Handbook of Social Movernents Across Disciplines, 2007) and the article (with Klandermans and van der Toorn) 'Embeddedness and Grievances: Collective Action Participation Among Immigrants' (American Sociological Review, 2008). She has edited (with Roggeband and Klandermans) The Future of Sociol Movement Research: Dynamics, Mechanisms and Processes (2013). She is currently conducting an international comparative study on street demonstrations with Klandermans and Walgrave: Caught in the Act of Protest: Contextualized Contestation (funded by European Science Foundation) and a study on emerging networks and feelings of belonging: The Evolution of Collective Action in Emerging Neighbourhoods (funded by Dutch Royal Academy of Science)
Ross Truscott is a postdoctoral research fellow working under the South African Research Chairs Initiative (SARChI) Chair for Social Change at the University of Fort Hare in East London, South Africa, and resident at the Center for Humanities Research at the University of the Western Cape, Cape Town, South Africa. He has published on post-Apartheid South African popular culture, race, psychoanalysis and postcolonialism.

Andreas Zick is Director of the Institute of Interdisciplinary Research on Conflict and Violence and Professor in the Department of Education Science at Bielefeld University, Germany. He has run several projects on intergroup relations including the study on Group-Focused Enmity in Europe. His primary research interests include prejudices in various contexts, acculturation processes and the radicalisation of violent individuals and groups. 
Sammut, G. and Bauer, M. (2011) 'Social Influence: Modes and Modalities'. In: Hook, D., Franks, B. and Bauer, M. eds. The Social Psychology of Communication. London: Palgrave. Scuzzarello, S. (2012) 'Migrants' integration in Western Europe: Bridging social psychology and political science'. Journal of Community \& Applied Social Psychology, 22: 1-19.

Soysal, Y. N. (1994) Limits of Citizenship: Migrants and Postnational Membership in Europe. Chicago: University of Chicago.

Staerklé, C. (2009) 'Policy attitudes, ideological values and social representations'. Social and Personality Psychology Compass, 3 (6): 1096-1112.

Staerklé, C., Clémence, A. and Spini, D. (2011) Social representations: A normative and dynamic intergroup approach'. Political Psychology, 32 (5): 759-768.

Stott, C. and Reicher, S. (2012) Mad Mobs and English Men. London: Constable \& Robinson.

Subašić, E., Reynolds, K., Reicher, S. and Klandermans, B. (2012) 'Where to from here for the psychology of social change? Future directions for theory and practice'. Political Psychology, 33 (1): 61-74.

Tajfel, H. (1981) Human Groups and Social Categories: Studies in Social Psychology. Cambridge: Cambridge University Press.

Thompson, J. B. (1990) Ideology and Modern Culture: Critical Social Theory in the Era of Mass Communication. Cambridge: Polity Press.

Uhlaner, C. J. (2001) 'Political Participation', In: Smelser, N. J. and Baltes, P. B. eds. International Encyclopedia of the Social and Behavioral Sciences. Oxford: Elsevier.

Vertovec, S. (2007). 'Super-diversity and its implications'. Ethnic and Racial Studies, 30 (6): 1024-1054.

Vygotsky, L. S. (1978) 'Mind in Society: The Development of Higher Psychological Processes'. In: Cole, M., John-Steiner, V., Scribner, S. and Souberman, E. eds. Mind in Society. Cambridge, MA: Harvard University Press.

Wieviorka, M. (2005) 'After new social movements'. Social Movement Studies, 4 (1): 1-19.

\section{3}

\section{Social Identity Theory and Self-Categorisation Theory}

Denis Sindic and Susan Condor

\section{Social Identity Theory and Self-Categorisation Theory}

Political behaviour always involves social groups, whether these take the form of concrete networks and gatherings of individuals such as pressure groups, demonstrations, governments, cadres or committees, or whether they are constituted as large-scale institutions or imagined communities (Anderson, 1991) such as polities, states, political parties, interest groups, publics, constituencies or electorates. In so far as social groups are central to politics, it follows that the psychology of groups should be relevant to our understanding of political psychology. Social Identity Theory (SIT) and Self-Categorisation Theory (SCT) represent major theoretical attempts to clarify the social-psychological processes associated with group membership and action and should, therefore, be in a good position to provide a significant contribution to that understanding. SIT developed from Tajfel's work on intergroup processes which focused on the genesis of conflict between social groups, as well as the factors which influence support for, or attempts to change, established social hierarchies (see, e.g., Tajfel, 1974, 1978a, 1978b; Tajfel and Turner, 1979). Turner (1982; Turner et al., 1987) later adopted some aspects of this approach as the basis for his SCT of group behaviour in general. Because the two theories share many key assumptions, they are often discussed under the general label of 'the Social Identity approach' or 'the Social Identity tradition'.

Early research adopting the Social Identity approach to intergroup relations often investigated real-world political behaviour, including political party affiliation (Kelly, 1988), trades union participation (Kelly and Kelly, 1994), the Northern Ireland conflict (Cairns and Mercer, 1984), Hindu-Muslim relations in India (Ghosh and Kumar, 1991) and responses to the Sino-British accord in Hong Kong (Bond and Hewstone, 1988). Tajfel's model, which emphasised how intergroup conflict could be rooted in concerns over collective identity as well as competition over material resources, was especially relevant to 
the New Social Movements that arose during the 1960s and 1970s (Reicher et al., 2010; Tajfel, 1978b), and social psychologists subsequently applied SIT to the women's movement (Williams and Giles, 1978) as well as ethnolinguistic minority group movements (Giles, 1977). Later, as SIT came to be increasingly adopted as a general metatheoretical perspective by social psychologists (Abrams and Hogg, 2004), fewer researchers focused on its particular relevance to political attitudes and action (see also Brewer, 2001; Huddy, 2001; Oakes, 2002; Reicher, 2004). However, the past decade has witnessed a renaissance of interest in the ways in which SIT and SCT might enhance social-psychological understanding of a range of formal and informal political behaviour, including party identification (Greene, 2004), political solidarity and affiliation (Subašić et al., 2008), leadership (Haslam et al., 2010; Hogg, 2001), political rhetoric (Hopkins and Kahani-Hopkins, 2004; Reicher and Hopkins, 1996a, 1996b, 2001), political participation and activism (Drury, 2012; Muldoon and Lowe, 2012; Thomas et al., 2009), schism (Sani and Pugliese, 2008), national separatism (Sindic and Reicher, 2009), conspiracy theorising (Sapountzis and Condor, 2013) and extremism (Baray et al., 2009; Hogg, 2012; Hopkins and Kahani-Hopkins, 2009).

It is now beyond the scope of a single chapter to provide a comprehensive overview of the ways in which the Social Identity approach might contribute to political psychology (see Ispas, 2013). Consequently, for the purposes of this chapter we will focus on two general issues. First, we will clarify, and where necessary distinguish, the key theoretical assumptions of SIT and SCT as they relate to political cognition and action. Second, because politics involves both groups and power, we will focus on some of the issues where the dynamics of identity and power intersect. This will include a consideration of the political consequences of identity management strategies, as well as a discussion of the particular case of politicised identities.

Social Identity Theory: Identity strategies and the dynamics of intergroup relations

Tajfel originally defined social identity as 'that part of an individual's selfconcept which derives from his knowledge of his membership in a social group (or groups) together with the value and emotional significance attached to that membership' (Tajfel, 1978a: 63). According to this perspective, group membership provides people with a sense of their distinct place in the social world (where they stand in relations to others) and acts as a practical guide to action by imparting the norms concerning the typical, appropriate or desirable forms of behaviour associated with a particular group membership. More specifically, Tajfel claimed that the processes associated with social (as opposed to personal) identity underpin intergroup (as opposed to interpersonal) behaviour. That is, to the extent that people see themselves inters in terms of group membership, and to the extent that they peranally identify with the social group to which they belong, they will tend sonally identify with the social group to which they belong, they will tend
to act towards others as group members rather than as unique individuto act towards others as group members rather than as unique individuapproach differed from existing social-psychological perspectives that often purt to explain intergroup behaviour with reference to the personality traits sought to explain interg (see, e.gu, Adorno et at, 1950). Indeed, one fundaof particular individuals (see, e.g., Adorno et al., 1950). Indeed, one fundamental assumption that underpins SIT is that groups and not individuals are the main engines of both social conflict and social change (Reicher et al., 2012).

SIT proposes a motivational element to intergroup behaviour (see, e.g., Tajfel and Turner, 1979) by suggesting that people are generally concerned to maintain, or to achieve, a positive sense of self, and that when they identify with social groups, this manifests itself in a need to perceive the groups to which they belong positively (for a review, see, e.g., Rubin and Hewstone, 1998). Moreover, SIT also proposes that social categories are necessarily defined and evaluated comparatively. Consequently, in order to achieve a positive evaluation of their comparatively. Consequently, in order to achieve a positive evaluation of their group, group members will be motivated to establish, and to maintain, a positive differentiation (i.e. positive distinctiveness) between in-group and relevant of groups consensually regarded as superior will confer a positive social identity, of confer a negative or unsatisfactory social identity, which may, under certain conditions, motivate the members of those groups to take collective action towards challenging the existing social hierarchy and the inferior status conferred to their group.

Of particular relevance to political psychology is the fact that SIT provides af model of the ideological context in which the identity management stratea model of the ideological context in which the identity management strate-
gies that people adopt to deal with an unsatisfactory social identity may be expected to lead to collective action (for more extended overview of identity management strategies, see, e.g., Blanz et al., 1998; Brown, 2000; Ellemers 1993; Haslam, 2001). The most important of these conditions is arguably the perceived permeability of group boundaries, that is, the extent to which peoperceived permeability of group boundaries, that is the petween social groups. In so far as members of socially devalued groups perceive individual mobility to be possible, they may respond to their inferior status by attempting to 'move up' the social hierarchy and by psychologically dis-identifying with the group to which they currently belong. However, when such mobility is perceived to be impossible or undesirable, people may engage in various forms of collective activity aimed at changing the comparative value associated with their group as a whole 
Tajfel described the latter situation as involving an ideology of social change. The term 'social change', however, is potentially misleading, since under these ideological conditions members of devalued groups will not necessarily attempt to challenge the existing intergroup hierarchy directly. According to SIT, the kind of collective activity that members of devalued social groups engage in will depend upon the perceived security of intergroup comparison (Tajfel, 1978a; Tajfel and Turner, 1979). Perceived security can be subdivided into two aspects. The first concerns the perceived legitimacy of the status quofor example, whether people assume that their inferior status has been justly ordained or deserved. The second concerns the availability of cognitive alternatives: the possibility of imagining changes to the existing intergroup status quo. Where existing intergroup hierarchies are perceived as legitimate, and/or where cognitive alternatives are not available, low status group members are unlikely to challenge the out-group directly. Instead, they may attempt to attain a positive social identity by strategically comparing their group with another of lower status; re-evaluating the labels and symbols conventionally associated with their group; or adopting strategies of social creativity to forge a favourable identity for their in-group on new dimensions of comparison. It is only when unfavourable intergroup comparisons are perceived as illegitimate and where cognitive alternatives are present that members of devalued social groups will engage in social competition and attempt to directly contest their inferior status.

Members of high status groups also have at their disposal a variety of strategies that mirror those of the low status groups, which may be used in an effort to maintain their position in the intergroup hierarchy. For example, they may attempt to make intergroup boundaries appear permeable by allowing a few out-group members to pass, but in proportion that remain largely symbolic (tokenism; see Wright and Taylor, 1998). Similarly, in an attempt to maintain existing social hierarchies, members of dominant social groups may seek to legitimate the status quo, for example, through reference to innate differences between human gender, nations or races.

\section{Social Identity Theory and the psychology of politics}

How can the model of social identity strategies proposed by SIT contribute to our understanding of political psychology? In general terms, the need and ability of humans to actively distinguish themselves from each other, which lies at the core of the theory, can be seen as both the condition of possibility and the very raison d'être of politics, if we define politics as that paradoxical human activity that both promotes differentiation between human beings and aims to deal with its problematic consequences (see, e.g., Arendt, 1958). However, a more restricted definition of politics is that it concerns the dynamics of power, and more specifically the processes of obtaining and using that power in public life. From that point of view, SIT's focus on the social-psychological evaluation of identities may appear to downplay the political aspects of intergroup relations, since the ultimate goal of identity management strategies has conventionally been understood as being about status rather than power. In so far as they have addressed issues of power, Social Identity theorists have tended to focus on the ways in which power may impact upon the quest for positive social identity, rather than focusing upon political power as a key probpostive social ident (see, e.g, Sachder and Bourhis, 1991). Moreover, there is a reser large proportion of SIT research that tends to treat power and status as synonymous, using terms like 'dominant/subordinate groups', 'high/low status groups' or 'majority/minority' interchangeably (for classic discussions of the distinction between the constructs of status and power, see Goldhamer and Shils, 1939; Weber, 1946).

Nevertheless, the potential relevance of SIT to political psychology becomes Nevertheless, the potential relevance of SIT to political psychology becomes
apparent once we appreciate how status and power are often related in practice. Changes in group status can act as catalyst for, or constitute an outcome of, political change, and conversely status inertia often go hand in hand with maintaining the political status quo. In practice the success of the various identity management strategies adopted by members of low status groups is likely tity management strategies adopted by members of low status groups is likely
to depend on the groups' access to power. Similarly, the extent to which a high status group may be able to (for example) convince others of their innate superiority is likely to depend on their effective control of media of education and communication as well as their privileged status per se. Conversely, the identity management strategies adopted by members of low status groups may not simply enhance the subjective value of their identity, but may also affect power relationships. In fact, there are always political consequences associated with the different strategies for achieving a satisfactory social identity, whether or not these are imagined or intended by the social actors concerned. For example, when individuals pursue a strategy of individual mobility, their choice makes it harder for other members of their group to organise any form of political or social resistance. In contrast, strategies of symbolic social competition (e.g. challenging existing group stereotypes) may help to mobilise group members to political action (Reicher et al., 1997). Overall, the identity dynamics described by SIT can therefore be said to be political in the sense that they both shape and are shaped by power dynamics.

However, there are also limits to the contribution of the theory to our understanding of political dynamics. First, as Rubin and Hewstone note (2004), although SIT does not preclude considerations of power and, indeed, invites a more detailed analysis of power dynamics and their interaction with identity processes, such analysis generally remains to be developed (but for recent developments in that direction, see Haslam et al., 2010; Simon and Oakes, 2006; Sindic et al., in press; Turner, 2005). 
Second, although most work adopting SIT has focused on struggles over status rather than conflicts over political power, there have been (as we noted earlier) notable exceptions as well as a recent revival of interest in applying SIT to political behaviour. However, any thoroughgoing attempt to apply SIT in this area requires a consideration of group behaviour which is directed at political goals in their own right. For that reason, it challenges what has for some become a key assumption of the theory, namely that all group action can necessarily and ultimately be understood as a quest for status. In that respect, it should be noted that the message in Tajfel's original writing was not that intergroup conflict could be reduced to social competition over status, but rather that this struggle should be understood as an intervening mechanism in conflicts over other type of goods (e.g. those who accept their negative identity are unlikely to challenge their political disadvantage since they see such inequalities as legitimate on the basis of their lower status). That is, Tajfel's primary concern was for the ways in which group identification provides the psychological basis for collective social action designed to challenge concrete economic and political as well as social inequalities. In that context, the struggle over status can represent but the means towards other ends, including political ones. This political preoccupation of Taifel is apparent if we consider, for instance, his views that stereotypes 'cannot be understood without a consideration of the functions they serve in the competitive and power relationships between the groups concerned' (Tajfel and Forgas, 1982: 133). It is true that the function of social differentiation (the role of stereotypes 'in helping to preserve or create positively valued differentiations between one's own and other social groups') centres on questions of group status. However, the functions of social explanation and social justification (the role of stereotypes 'in contributing to the creation and maintenance of group "ideologies" explaining or justifying a variety of social actions') are clearly "oriented towards political goals (p. 134).

Finally, one can question the extent to which SIT is able to deal with the specific phenomena of politicised identities, that is with collective identities that are normatively defined in terms of an explicit political commitment and where group members are consciously aware of being part of a power struggle (Simon and Klandermans, 2001). At present, SIT remains somewhat unclear on the extent to which the eventual political consequences of identity management strategies can be traced back to the deliberate intent of the social actors concerned. For example, a white comedian making a joke about black people may very well contribute to perpetuate negative stereotypes about black people and thereby help to maintain their lower status and subordinate position in society. However, the immediate goal of the comedian might really be only to make other people laugh (Condor, 1990). That is, there may not be any explicit political intent behind the joke, nor any awareness by the comedian of 'white people' as a politicised identity, involved in a power struggle with 'black people' - contrary to, say, the case of a white supremacist making the exact same joke (Billig, 2005). At present, SIT does not really allow us to differentiate clearly between those two cases, despite the fact that they do differ in important respects.

Thus, despite their pervasive political consequences, it is not clear whether the social identity dynamics described by SIT can be called political in the full sense of the term. This, of course, does not mean that such identity processes are irrelevant to our understanding of politicised identities, but rather that the generic focus of the theory may need to be complemented by other approaches tailored to tackle this more specific issue. There are, in fact, other specific characteristics of politicised identities that the theory has difficulties with, which will be addressed after we review SCT.

\section{Self-Categorisation Theory}

As noted above, SIT proposes that people act in terms of their social identity whenever they see themselves and others in terms of group membership rather than as particular individuals. Another way to put this is that social identity processes come into play when people categorise themselves (and others) as group members. SCT focuses on the nature, antecedents and consequences of this psychological process of self-categorisation.

In terms of the nature of the process, SCT postulates that when we selfcategorise as group members we come to see ourselves as similar to (and interchangeable with) other in-group members on the key stereotypical aspects that define the group, a process termed depersonalisation. This does not involve a loss of selfhood (as is the case in deindividuation, see Reicher et al., 1995), but involves the experience of the self as defined by group membership rather than by unique individual characteristics. This is very close to SIT's notion of social identification, but one key difference is that in SCT social categories are always part of a hierarchical structure as a function of their level of inclusiveness. Fo example, Simon may see himself as a unique individual when among friends, as a political psychologist when comparing himself to cognitive psychologists, as a social scientist when comparing himself to natural scientists and all the way up to defining himself as a human in comparison to other species. Thus, the choice is not between different unrelated identities but between different identities nested into each other.

identities nested into each other.
One implication of this hierarchical structure is that a particular category or identity is not solely defined by its comparison with another group situated on the same level of categorisation. Its definition also depends upon its relation with the level of categorisation immediately above it. In particular the superordinate category that encompasses both in-group and out-group(s) provides the specific dimensions of comparisons along which the groups are 
contrasted. This is because the superordinate category defines the prototype of what the groups should be like. For example, members of national groups will not compare themselves along any random dimension, but along the prototypical characteristics of a great or a good nation. This factor may help to explain why groups often choose to compete on the same dimension of comparison. It also alerts us to the ways in which political arguments often relate not only to the outcome of intergroup comparisons (e.g. whether 'our' political party is better or worse than another), but to the prototype of the superordinate cat egory (what political parties, in general, should be like). Consequently, group members may be inclined to define superordinate categories in such a way as to favour their own group over relevant out-groups in the ensuing intergroup comparisons (Mummendey and Wenzel, 1999).

In terms of the antecedents of the self-categorisation process, the main question addressed by SCT relates to the question of why any particular categorisation should be psychologically salient in a particular context. Following ideas first outlined by Bruner (1957), SCT proposes that the psychological salience of a particular level of self-categorisation is determined through an interaction of accessibility and fit (Oakes, 1987; Turner et al., 1994). Accessibility, or perceiver readiness, refers to an individual's readiness to use a given set of categories as a function of past experience, present expectations, motives, values, goals and needs (which includes all the factors contributing to long-term social identification). The concept of fit concerns the relationship between the nature of categories and external reality and can be divided into two aspects. Comparative fit refers to the relationship between categories and the distribution of intragroup versus intergroup differences: the set of categories that maximise the ratio of intergroup differences compared to intragroup differences will be most salient. Normative fit refers to the fact that the specific content of these differences should match the stereotypical expectations associated with these categories. For instance, if a group discussion is split on a question of welfare spending, with some people arguing for more support for unemployed people and others for less, political orientation is likely to become salient, and participants are likely to categorise themselves as liberals versus conservatives, because the categories account for the differences in orientation adopted by individuals and also because such differences are in line with existing stereotypes concerning political ideology.

In terms of the consequences of self-categorisation processes, the principles outlined by SCT have been applied to many different areas (see, e.g., Haslam, 2001; Turner et al., 1987), but there is one area in particular that has perhaps received the most attention and that is also directly relevant to our understanding of politics, namely the processes of social influence (Turner, 1991). Social influence is key to many political processes, including the spread of political ideas, elections and voting, political mobilisation and the very nature of political power (Lukes, 2005). For SCT, social influence does not depend solely on the characteristics of the message, the messenger and/or the audience (see Hovland et al, 1953). It also depends on the relationship between messenger and audience that is established by the self-categories employed in a particular social context.

Specifically, the consequences of the process of self-categorisation on influence are threefold. First, the nature of the salient self-categories will determin who we can influence and who we should be influenced by. That is, the process of self-categorisation creates the expectation that we will agree with other in-group members and disagree with out-group members (Abrams et al., 1990), so that social influence should only take place in the former case since only people sharing a common group membership will try and reach a consensus. Second the specific content (i.e. stereotypes, norms and values) associated with the salient self-category will determine who, among in-group members, will be seen as prototypical (i.e. embodying the groups' spirit and values) and is therefore more likely to be influential. Finally, the specific content of in-group identity also sets limits on the nature of the messages that can be influential: influence will be limited to messages which are seen to be consistent with the group stereotypes, values and norms.

These processes are also important for the related phenomenon of leadership. SCT focuses not merely on the personal qualities that make a good leader but also on the relationships between leaders and followers (see, e.g., Haslam et al., 2010). According to SCT, effective leaders need to present themselves as embodying the group's identity and will, but followers are not passive in that process since they help define the dimensions along which the prototypicality of a potential leader will be assessed. Thus followers 'make' the leader as much as the leader 'attracts' followers.

\section{The Social Identity tradition and the psychology} of politics revisited

By way of conclusion, we return to the issue of how the Social Identity approach (this time with the inclusion of SCT) might help our understanding of politicised identities. We have already suggested that politicised identities possess specific features that make them more than just one type of identity among many. One important factor is that the power dynamics in which politicised identities are involved can only make sense in the context of a common superordinate group. A political protest for equal rights between blacks and whites, for instance, can only make sense if we invoke a superior category that provetween groups and their legitimacy are made (e.g. black people de between groups and their legitimacy are made (e.g. black people deserve the same rights as white people because they are all human beings). SIT's focus 
on the nuclear situation of two groups in a dyadic relationship, apparently isolated from their relationships to other groups and the rest of society, might lead to disregard this aspect. However, SCT's tenet that the relationships between groups is always mediated by their common membership into a shared superordinate category (which provides the dimensions of intergroup comparisons) highlights this important aspect of political cognition and rhetoric.

The relationship of groups to a superordinate category can also help to account for two supplementary and related facts about political behaviour. First, a great deal of political action is not (or not only) simply directed at the outgroup per se but at a more general audience (Simon and Klandermans, 2001). Those who argue for the extension of rights for ethnic minority groups, for instance, have probably little hope to be heard by those against whom they protest. Rather, their call for justice may be directed not only towards fellow ingroup members (Reicher and Hopkins, 2001) but also towards the larger public who may possibly be won to their cause (Condor et al., 2013). This is illustrated by protesters all over the globe using protest signs written in English, even when the protest is taking place in a non-English-speaking country. The attempt to mobilise a 'universal audience' (see Condor et al., 2013) only makes sense if protesters assume that, because of their common superordinate membership, people from other groups may share the same dimensions of judgement and thus should be able to assess the legitimacy of their claim.

Second, political groups do not always act in terms of the interest of their own group defined in narrow terms. Political parties, for instance, do not claim to act solely for the benefit of their own party, but for the benefit of the country as a whole. Conflict between parties, then, is shaped not only by the relation of one group to another but by their common relationship to a superordinate category. The latter not only defines the 'rules of engagement', but the possibility to steer its direction and fulfil its interests maỳ be what is ultimately at stake. This is why claims about the prototypicality of the in-group in relation to the superordinate category (e.g. that 'we' better represent what our compatriots are like and what they want) can be made for political reasons (Sindic and Reicher, 2008).

Nevertheless, there are at least two other issues related to politicised identities with which the Social Identity tradition currently struggles. First, although both SIT and SCT assume that the ideological/political/cultural context and the specific contents of identities play a key role in determining the outcomes of psychological processes, the psychological processes themselves are assumed to remain invariate. Certainly, there may be common psychological processes that characterise all types of social identities, but there may also be specific processes associated with different types of identities and their specific contents and ideological frameworks. For instance, the adoption of particular ideological frames of reference (e.g. communitarian vs. liberal; see Condor and Abell, 2006) about national identities may lead people to embrace different reflexive stances towards their own identity, and thereby to develop complex relationships with that identity that go beyond the simple identification/dis-identification dichotomy.

The particular content and ideological context of politicised identity may well vary, but must necessarily be related to principles of a political nature, such as legitimacy, justice, fairness and the right to self-determination. To express this argument in the terminology of SCT, the dimensions of intergroup comparison provided by the superordinate category must be relevant to the political claims - in the same way that, for instance, moral categories must be based on dimensions that can inform moral claims. The fact that the SI approach has tended to assume that identical processes underlie all forms of social identity means that it cannot enlighten us about the differences between (to pursue the example) political and moral identities.

Second, and finally, another key characteristic of politicised identities lies in their 'essential contestedness' (Gallie, 1956; Swanton, 1985), that is, the fact that they are not only open to contestation, but that they will inevitably be contested since that contestation is a natural correlate of the political dynamics in which they are involved. Any definition of European identity, for instance, is bound to have implications for the (il)legitimacy of political integration at the European level (Duchesne, 2008; Sindic, 2010), and it is precisely because of those political implications that it is actively and consciously contested.

This essential contestedness can be seen as a logical consequence of the processes described by both SIT and SCT. At the same time, however, it is also a factor that they are somewhat ill-equipped to handle. Thus on the one hand, since both theories emphasise how identities have key consequences for social influence and political mobilisation, it is only logical to infer that those who wish to shape the political opinions and actions of others will attempt to formulate and disseminate particular definitions that suit their specific political purposes. Put differently, it is the various attempts to create political consensus that gives rise to political contestation over the meaning of politicised identities (Haslam et al., 1998; Reicher and Hopkins, 2001). Empirically, studies show that those who attempt to mobilise support for a political project use argumentative principles that are remarkably in line with SCT's principles, such as maximising the scope of the in-group, minimising the scope of the out-group and defining the content of in-group identity in order to make it normatively consonant with their message (Reicher and Hopkins, 1996a, 1996b).

On the other hand, the way in which both SIT and SCT describe the contextual antecedents of identity contents leaves little theoretical room for such purposeful contestation. In SIT, perceptions of permeability, legitimacy and stability are typically taken for granted as a point of departure from which questions as to their consequences are being addressed (Reicher, 1996), and the question of what, in turn, shape those perceptions is often deferred to other 
disciplines such as sociology or social history (Tajfel, 1979). This suggests a view where the contents of social identities are the results of sociological and historical forces beyond purposeful human agency. In SCT, this is even more apparent since the perceived content of categories is aimost entirely and mechanically determined by the immediate comparative and normative social context. Yet, it is a key part of the political process itself - perhaps even one of its most essential characteristics and purposes - to contribute to the elaboration of the meaning of social and political realities, such as who we should compare ourselves with and on what dimensions; what is and what is not legitimate; and what can or cannot be changed.

\section{References}

Abrams, Dominic, and Hogg, Michael A. (2004) 'Metatheory: Lessons from social identity research'. Personality and Social Psychology Review, 8: 98-106.

Abrams, Dominic, Wetherell, Margaret S., Cochrane, Sandra, Hogg, Michael A., and Turner, John C. (1990) 'Knowing what to think by knowing who you are: Selfcategorization and the nature of norm formation, conformity and group polarization' British Journal of Social Psychology, 29: 97-119.

Adorno, Theodor W., Frenkel-Brunswik, Else, Levinson, Daniel J. and Sanford, R. Nevitt. (1950) The Authoritarian Personality. New York: Harper and Row.

Anderson, Benedict. (1991) Imagined Communities: A Reflection on the Origin and the Spread of Nationalism, Revised ed. London: Verso.

Arendt, Hannah. (1958) The Human Condition. Chicago: University of Chicago Press.

Baray, Gamze, Postmes, Tom and Jetten, Jolanda. (2009) 'When I equals we: Exploring the relation between social and personal identity of extreme right-wing political party members'. British Journal of Social Psychology, 48: 625-647.

Billig, Michael. (2005) 'Violent racist humour'. In: Lockyer, Sharon and Pickering, Michael eds. Beyond a Joke: The Limits of Humour. Basingstoke: Palgrave Macmillan, pp. 25-44.

Blanz, Mathias, Mummendey, Amélie, Mielke, Rosemarie and Klink, Andreas. (1998) 'Responding to negative social identity: A taxonomy of identity management strategies'. European Journal of Social Psychology, 28: 697-729.

Bond, Michael H. and Hewstone, Miles. (1988) 'Social identity theory and the perception of intergroup relations in Hong Kong'. International Joumal of Intercultural Relations, 12 $153-170$

Brewer, Marylinn. (2001) "The many faces of social identity: Implications for political psychology'. Political Psychology, 22: 115-125.

Brown, Rupert. (2000) 'Social Identity Theory: Past achievements, current problems and future challenges'. European Journal of Social Psychology, 30: 745-778.

Bruner, Jerome S. (1957) 'On perceptual readiness'. Psychological Review, 64: 123-152.

Cairns, Ed. and Mercer, G. William. (1984) 'Social identity in Northern Ireland. Human Relations, 37: 1095-1102

Condor, Susan. (1990) 'Social stereotypes and social identity'. In: Abrams, Dominic and Hogg, Michael A. eds. Social Identity Theory: Constructive and Critical Advances. Hemel Hempstead: Harvester Wheatsheaf, pp. 230-249.
Condor, Susan and Abell, Jackie. (2006) 'Romantic Scotland, tragic England, ambiguous Britain: Constructions of "the Empire" in post devolution national accounting'. Nations and Nationalism, 12: 453-472.

Condor, Susan, Tileaga, Cristian and Billig, Michael. (2013) 'Political rhetoric'. In: Huddy, Leonie, Sears, David O. and Levy, Jack S. eds. Oxford Handbook of Political Psychology. Oxford: Oxford University Press, pp. 262-297.

Drury, John. (2012) 'Prejudice is about politics: A collective action perspective'. Behavioral and Brain Sciences, 35: 20-21.

Duchesne, Sophie. (2008) 'Waiting for European identity ... Preliminary thoughts about the identification process with Europe'. Perspectives on European Politics and Society, 9: $397-410$.

Ellemers, Naomi. (1993) 'The influence of socio-structural variables on identity enhancement strategies'. European Review of Social Psychology, 4: 27-57.

Gallie, Walter B. (1956) 'Essentially contested concepts'. Proceedings of the Aristotelian Society, 56: 167-198.

Ghosh, Emanuel S. K. and Kumar, Rashmi A. (1991) 'Hindu-Muslim intergroup relations in India: Applying socio-psychological perspectives'. Psychology and Developing Societies, 3: $93-112$.

Giles, Howard. (Ed.) (1977) Language, Ethnicity, and Intergroup Relations. London: Academic Press.

Goldhamer, Herbert and Shils, Edward A. (1939) 'Types of power and status'. American Journal of Sociology, 45: 171-182

Greene, Steven. (2004) 'Social identity theory and party identification'. Social Science Quarterly, 85: 136-153.

Haslam, S. Alexander. (2001) Psychology in Organizations: The Social Identity Approach. London: Sage.

Haslam, S. Alexander, Reicher, Stephen D. and Platow, Michael J. (2010) The New Psychology of Leadership. Hove: Psychology Press.

Haslam, S. Alexander, Turner, John C., Oakes, Penelope J., McGarty, Craig and Reynolds, Katherine J. (1998) 'The group as a basis for emergent stereotype consensus'. European Review of Social Psychology, 8: 203-239.

Hogg, Michael A. (2001) 'A social identity theory of leadership'. Personality and Social Psychology Review, 5: 184-200.

Hogg, Michael A. (2012) 'Self-uncertainty, social identity and the solace of extremism'. In: Hogg, Michael A. and Blaylock, Danielle L. eds. Extremism and the Psychology of Uncertainty. Boston: Wiley-Blackwell, pp. 19-35.

Hopkins, Nick and Kahani-Hopkins, Vered. (2004) 'Identity construction and British Muslims' political activity: Beyond rational actor theory'. British Journal of Social Psychology, 43: 339-356.

Hopkins, Nick and Kahani-Hopkins, Vered. (2009) Reconceptualizing 'extremism' and 'moderation'. British Tournal of Social Psychology, 48: 99-113.

Hovland, Carl I., Janis, Irving L. and Kelley, Harold H. (1953) Communication and Persuasion: Psychological Studies of Opinion Change. New Haven: Yale University Press. Huddy, Leonie. (2001) 'Trom social to political identity: A critical examination of social identity theory'. Political Psychology, 22: 127-156.

Ispas, Alexa. (2013) Psychology and Politics: A Social Identity Perspective. New York: Psychology Press.

Kelly, Caroline. (1988) 'Intergroup differentiation in a political context'. British Journal of Social Psychology, 27: 319-332. 
Kelly, Caroline and Kelly, John. (1994) 'Who gets involved in collective action?'. Human Relations, 47: 63-88.

Lukes, Steven. (2005) Power: A Radical View, 2nd Ed. Basingstoke: Palgrave Macmillan. Muldoon, Orla T, and Lowe, Robert D. (2012) 'Identity, conflict and the experience of trauma: The social psychology of intervention and engagement following political violence'. In: Jonas, Kai J. and Morton, Thomas A. eds. Restoring Civil Societies. Oxford: Wiley-Blackwell, pp. 208-221.

Mummendey, A. and Wenzel, M. (1999) 'Social discrimination and tolerance in intergroup relations: Reactions to intergroup difference'. Personality and Social Psychology Review, 3, 158-174

Oakes, Penelope J. (1987) 'The salience of social categories'. In: Turner, John C., Hogg, Michael A, Oakes, Penelope J., Reicher, Stephen D. and Wetherell, Margaret S. eds. Rediscovering the Social Group: A Self-Categorization Theory. Oxford: Blackwell, pp. $117-141$.

Oakes, Penelope J. (2002) 'Psychological groups and political psychology'. Political Psychology, 22: 809-824.

Reicher, Stephen D. (1996) 'Social identity and social change: Rethinking the context of social psychology'. In: Robinson, W. Peter ed. Social Groups and Identities: Developing the Legacy of Henri Taifel. Oxford: Butterworth Heinemann, pp. 317-336.

Reicher, Stephen D. (2004) 'The context of social identity: Domination, resistance, and change'. Political Psychology, 25: 921-945.

Reicher, Stephen D. and Hopkins, Nick. (1996a) 'Seeking influence through characterizing self-categories: An analysis of anti-abortionist rhetoric'. British Journal of Social Psychology, 35: 297-311.

Reicher, Stephen D. and Hopkins, Nick. (1996b). 'Self-category constructions in political rhetoric; an analysis of Thatcher's and Kinnock's speeches concerning the British miners' strike (1984-5)'. European Journal of Social Psychology, 26: 353-371.

Reicher, Stephen D. and Hopkins, N. (2001). Self and Nation: Categorization, Contestation and Mobilization. London: Sage.

Reicher, Stephen D., Hopkins, Nick and Condor, Susan. (1997) 'Stereotype construction as a strategy of influence'. In: Spears, Russell, Oakes, Penelope J., Ellemers, Naomi and Haslam, S. Alexander eds. The Social Psychology of Stereotyping and Group Life. Oxford: Blackwell Publishers, pp. 94-118.

Reicher, Stephen D., Spears, Russell, and Haslam, S. Alexander. (2010) 'The social identity approach in social psychology'. In: Wetherell, Margaret S. and Mohanty, Chandra T. eds. The SAGE Handbook of Identities. London: Sage, pp. 45-62

Reicher, Stephen D., Spears, Russell and Postmes, Tom. (1995) 'A social identity model of deindividuation phenomena'. In: Stroebe, Wolfgang and Hewstone, Miles eds. European Review of Social Psychology, vol. 6. Chichester, England: Wiley, pp. 161-198.

Reicher, Stephen D., Haslam, S. Alexander, Spears, Russell and Reynolds, Katherine J. (2012) 'A social mind: The context of John Turner's work and its influence'. In Stroebe, Wolfgang and Hewstone, Miles eds. European Review of Social Psychology, Vol. 23. Oxon, UK: Psychology Press, pp. 344-385.

Rubin, Mark and Hewstone, Miles. (1998) 'Social identity theory's self esteem hypothesis: A review and some suggestions for clarification'. Personality and Social Psychology Review, 2: $40-62$.

Rubin, Mark, and Hewstone, Miles. (2004) Social identity, system justification, and social dominance: Commentary on Reicher, Jost et al., and Sidanius et al.'. Political Psychology, 25: 823-844.
Sachdev, Itesh and Bourhis, Richard Y. (1991) Power and status differentials in minority/majority group relations. European Journal of Social Psychology, 21: 1-24.

Sani, Fabio and Pugliese, Annarita C. (2008) 'In the name of Mussolini: Explaining the schism in an Italian right-wing political party'. Group Dynamics, 12: 242-253.

Sapountzis, Antonis and Condor, Susan. (2013) 'Conspiracy accounting as intergroup theory'. Political Psychology, 34: 731-752.

Simon, Bernd and Klandermans, Bert. (2001) 'Politicized collective identity. A social psychological analysis'. American Psychologist, 56: 319-331.

Simon, Bernd and Oakes, Penelope J. (2006) 'Beyond dependence: An identity approach to social power and domination'. Human Relations, 59: 105-139.

Sindic, Denis. (2010) National Identity, Separatism, and Supra-nation Integration: Attitudes towards Britain and Europe in Scotland. Saarbrücken: VDM Verlag Müller.

Sindic, Denis, Barreto, Manuela and Costa-Lopes, Rui. (in press) The Intersection of Power and Identity. Hove: Psychology Press.

Sindic, Denis and Reicher; Stephen D. (2008) 'The instrumental use of group prototypicality judgments'. Joumal of Experimental Social Psychology, 44: 1425-1435.

Sindic, Denis and Reicher, Stephen D. (2009). 'Our way of life is worth defending: Testing a model of attitudes towards superordinate group membership through a study of Scots' attitudes towards Britain'. European Journal of Social Psychology, 39: 114-129.

Subašić, Emina, Reynolds, Katherine J. and Turner, John C. (2008) 'The political solidarity model of social change: Dynamics of self-categorization in intergroup power relations'. Personality and Social Psychology Review, 12: 330-352.

Swanton, Christine. (1985) 'On the 'essential contestedness' of political concepts'. Ethics, 95: 811-827.

Tajfel, Henr. (1974) 'Social identity and intergroup behaviour'. Social Science Information, 13: 65-93.

Tajel, Henri. (Ed.) (1978a). Differentiation between Social Groups: Studies in the Social Psychology of Intergroup Relations. London: Academic Press.

Tajfel, Henri. (1978b). The Social Rychology of Minonites. London: Mhority Rights Group. Tajfel, Henri. (1979). 'Individuals and groups in social psychology'. British Journal of Social and Clinical Psychology, 18: 183-190.

Tajfel, Henri. and Turner, John C. (1979). 'An integrative theory of intergroup relations'. In: Worchel, Stephan and Austin, William G. eds. The Social Psychology of Intergroup Relations. Monterey, CA: Brooks-Cole, pp. 33-47.

Tajfel, Henri. and Forgas, Joseph P. (1982) Social categorization: Cognitions, values, and groups'. In: Forgas, Joseph P. ed. Social Cognition: Perspective on Everyday Understanding. London: Academic Press, pp. 113-140.

Thomas, Emma F., McGarty, Craig and Mavor, Kenneth 1. (2009) 'Aligning identities, emotions and beliefs to create commitment to sustainable social and political action'. Personality and Social Psychology Review, 13: 194-218.

Turner, John C. (1982) 'Towards a cognitive redefinition of the social group'. In: Tajeel, Henri ed. Social Identity and Intergroup Relations. Cambridge: Cambridge University Press, pp. $15-40$

Turner, John C. (1991) Social Influence. Milton Keynes: Open University Press.

Turner, John C. (2005) 'Explaining the nature of power: A three-process theory'. European Toumal of Social Psychology, 35: 1-22.

Turner, John C., Oakes, Penelope J., Haslam, S. Alexander and McGarty, Craig. (1994) 'Self and collective: Cognition and social context'. Personality and Social Psychology Bulletin, 20: 454-463. 
Turner, John C., Hogg, Michael A., Oakes, Penelope J., Reicher, Stephen D. and Wetherell, Margaret S. (1987) Rediscovering the Social Group: A Self-Categorization Theory. Oxford: Blackwell.

Weber, Max. (1946) 'Class, status and party'. In: Gerth, Hans and Wright Mills, Charles eds. From Max Weber: Essays in Sociology. New York: Oxford University Press, pp. $180-195$.

Williams, Jennifer A. and Giles, Howard. (1978) 'The changing status of women in society'. In: Tajfel, Henri ed. Differentiation between Social Groups. London: Academic Press, pp. $431-436$.

Wright, Stephen C. and Taylor, Donald M. (1998) 'Responding to tokenism: Individual action in the face of collective injustice'. European Joumal of Social Psychology, 28: $647-667$

\section{4 \\ Psychoanalysis as Political Psychology}

Stephen Frosh

\section{Introduction}

Psychoanalysis has a mixed reputation as a source of political understanding. On the one hand, it is an individualistic discipline that focuses on privatised psychotherapeutic work. In this clinical context, which is its major one and in which most of the creativity and development of psychoanalysis has been located, the tradition is to bracket off the social and political and focus instead either on the purely 'internal' - the impulses, wishes or desires of the 'analysand' - or on the relational, constituted by the 'use' made by the analysand of the analyst under the guise of the transference. Despite various interventions that draw attention to the way the individual in such an encounter is already unavoidably constituted, in part or whole, by the sociopolitical context (e.g. Layton et al., 2006), and despite the commitment of many psychoanalysts to progressive social causes, analytic practice tends to stay firmly within these psychological boundaries. In some respects, one might argue that this is appropriate: after all, the trade of psychoanalysts is in the speech of their patients, with the affects to which it gives rise and the unconscious ideas it is assumed to reveal, and that is all they know and all they can deal with. If, that is, psychoanalysis is a practice of speech, as Lacanian psychoanalysts in particular are wont to assert (Parker, 2010), then perhaps it is only right that analysts maintain a studied agnosticism towards the political situation. They have no more access to it, or understanding of it, than anyone else; their area of expertise, such as it is, lies in interpreting speech and exploring the unconscious manoeuvres that surround it; their task is to listen,

This chapter is adapted from Chapter 6 of Stephen Frosh (2010) Psychoanalysis Outside the Clinic. London: Palgrave. 